\title{
Perbaikan Proses Pengujian Qualitas Pada Produk Donut Mix Untuk Meningkatkan Produktivitas
}

\section{Improving the Quality Testing Process for Donut Mix Products for Increase Productivity}

\author{
Nur Fadilah Fatma ${ }^{1}$, Henri Ponda ${ }^{2}$, Dian Yuliani ${ }^{3}$ \\ 1,2,3Program Studi Teknik Industri, Universitas Muhammadiyah Tangerang, Jalan Perintis Kemerdekaan I \\ No.33, Cikokol, Babakan, Kota Tangerang, Banten, 15118, Indonesia \\ ${ }^{1}$ nurfadilah.fatma@umt.ac.id, 2henri_ponda@umt.ac.id
}

\begin{abstract}
ABSTRAK
Sebuah perusahaan, akan mengalami proses pasang surut dimana hal tersebut merupakan hal yang lumrah terjadi. Pada akhir tahun 2020, dunia dikejutkan dengan menjadinya pandemic sebuah virus bagi seluruh belahan dunia. Dampak dari pandemic ini menyebabkan pengurungan karyawan sebagaimana dalam perusahaan ini. Sehingga membuat produktifitas menurun khususnya di department Quality. Untuk menghadapi hal ini maka perusahaan meminta kepada karyawan utuk melakukan perubahan dalam flow process pengujian sampel, untuk mengidentifikasi aktivitas aktivitas yang non value added. Sehingga mengakibatkan terganggunya proses pengiriman dan banyak sampel yang tertumpuk. Tujuan penelitian ini adalah untuk mengidentifikasi dan melakukan rencana perbaikan yang menyebabkan aktivitas non value added. Penelitian ini menggunakan metode Fault Tree Analysis (FTA) dan 5W1H. Pada analisis FTA menunjukan bahwa penyebab aktivitas non value added adalah proses mixing terlalu lama, terlalu banyak proses saat moulding dan proses proofing terlalu lama. Berdasarkan analisis FTA ini dapat ditentukan prioritas rencana tindakan perbaikan untuk melaksanakan perbaikan tersebut. Rencana perbaikan menggunakan metode $5 \mathrm{~W} 1 \mathrm{H}$ yaitu meriview ulang metode pengujian yang ada saat ini. Hasil dari penelitian ini sangat efektif karena mampu menurunkan waktu proses sebesar 59 menit.

Kata Kunci: Fault Tree Analysis, 5W1H, flow process, efektivitas dan pandemi.
\end{abstract}

\section{ABSTRACT}

A company, will experience a process of ups and downs where this is a common thing. At the end of 2020, the world was shocked by the corona virus pandemic in all parts of the world. The impact of this pandemic has led to the confinement of employees as in this company. So that it makes productivity decrease, especially in the Quality department. To deal with this, the company asks employees to make changes in the sample testing flow process, to identify non-value-added activities. This resulted in disruption of the shipping process and many samples piled up. The purpose of this study is to identify and plan improvements that lead to non-value-added activities. This study uses the Fault Tree Analysis (FTA) and 5W1H methods. The FTA analysis shows that the cause of non-value-added activity is the mixing process is too long, too many processes during molding and the proofing process is too long. Based on this FTA analysis, priorities for corrective action plans can be determined to implement these improvements. The improvement plan uses the $5 \mathrm{WlH}$ method, which is to review the current test methods. The results of this study were very effective because they were able to reduce the processing time by 59 minutes. Keywords: Fault Tree Analysis, 5W1H, flow process, effectiveness and pandemic. 


\section{PENDAHULUAN}

Sebuah perusahaan, akan mengalami kesulitan dalam menjalankan bisnisnya dimana hal tersebut merupakan hal yang sudah biasa terjadi. Hal ini bisa disebabkan oleh beberapa faktor seperti faktor internal dan faktor eksternal.salah satu faktor internal penyebab sebuah perusahaan mengalami pasang surut bisa berupa konflik-konflik yang terjadi di dalam perusahaan tersebut, seperti produktifitas yang menurun, kinerja karyawan yang kurang baik, fasilitas yang kurang mendukung, dan lain-lain. Sedangkan salah satu faktor eksternalnya bisa berupa hal-hal yang berasal dari luar perusahaan, seperti kondisi politik di negara tersebut, kondisi ekonomi, teknologi dan ekologi atau lingkungan.

Pada tahun 2020, Indonesia dikejutkan dengan mewabahnya Corona virus (Covid19) yang berasal dari Tiongkok. Wabah tersebut menjadi pandemi di seluruh dunia, yang mana banyak berpengaruh terhadap sendi kehidupan manusia, terutama segi ekonomi. Dengan adanya pandemi tersebut, tidak sedikit perusahaan di berbagai belahan dunia yang memutuskan untuk melakukan PHK besar-besaran terhadap karyawannya.

Salah satunya terjadi pada salah satu perusahaan dalam penelitian ini yang bergerak dalam bidang industri makanan dan minuman, ikut merasakan dampak dari pandemi ini. Puncaknya, pada Q1 dan Q2 2020, perusahaan terpaksa melakukan pengurangan karyawan dikarenakan keuangan perusahaan sedang tidak stabil, sehingga perusahaan mengurangi personil, khususnya karyawan kontrak dan harian lepas pada departemen Quality. Departemen Quality yang semula beranggotakan 3 orang, kini harus mengalami kekurangan personil, menjadi 1 orang. Dengan kondisi saat ini dapat dipastikan bahwa sampel-sampel produk yang ada akan terpending karena personil yang ada tidak cukup untuk melakukan proses inspeksi.

Akibat dari pengurangan personil tersebut, tim Quality tidak bisa menyelesaikan sampel-sampel secara tepat waktu. Sedangkan data status mutu produk dari hasil pengecekan tersebut, amat sangat dibutuhkan oleh tim produksi dan tim PPIC. Tak jarang, tim PPIC dan tim Produksi memberikan status "urgent" pada sampel produk yang diharapkan mendapatkan penanganan segera dari tim Quality.

Menurut James R. Evans (1994), kinerja yang rendah menyebabkan perusahaan sulit menjual produk domestik maupun Pasar internasional, sulit mencapai tujuan perusahaan seperti kesehatan, pendidikan, dan kesejahteraan sosial. Selain itu, produktivitas yang rendah berakibat pada tingginya harga jual dan meningkatnya kebutuhan akan sumber - sumber masukan. yang selanjutnya akan mendorong inflasi. Sebaliknya, produktivitas yang tinggi dapat berdampak pada penurunan biaya operasi sehingga mendukung daya saing, peningkatan keluaran industri dan keuntungan sehingga menciptakan lebih banyak pekerjaan, serta perbaikan kepuasan dan semangat kerja. Produktivitas adalah sebuah konsep yang menggambarkan kaitan antara keluaran atau hasil yang dicapai dengan sumber atau masukan yang digunakan untuk mencapai hasil (J Sadiman,1983).

Karena hal ini perlu adanya perbaikan metode pengujian yang efisien Agar sampelsampel produk tetap dapat dikerjakan tepat waktu dan tanpa ada penumpukan sampel selanjutnya. Untuk itu, tim Quality perlu memikirkan cara yang efisien dan efektif dalam menangani permasalahan tersebut.

Salah satu metode Analisa deduktif untu mengidentifikasi terjadinya kerusakan pada system dengan cara menggambarkan alternatif -alternatif kejadian dalam suatu blok diagram secara terstruktur adalah menggunakan Fault Tree Analysis (FTA) hal ini menurut Papadopoulos (2004). 


\section{METODOLOGI}

Langkah awal penelitian yaitu merencanakan tempat penelitian dan metode apa yang akan digunakan, tempat untuk peneltian yaitu salah satu perusahaan yang berada di Tangerang yang bergerak dibidang makanan dan minuman yang sedang berkembang. Metode yang akan digunakan dalam penelitian ini yaitu metode Fault Tree Analysis. Dan melakukan studi lapangan atau pengamatan serta mengimplementasikan pada proses pengerjaan sampel di perusahaan tersebut.

Kemudian dilakukan pengumpulan data, dan data yang ditampilkan yaitu alur proses pengujian sampel QC, setelah data terkumpul maka data akan diolah dengan metodologi penelitian Fault Tree Analysis. Setelah itu penulis menganalisa data dan pembahasan solusi yang akan dilakukan.

Tahap terakhir yaitu kesimpulan dan saran dimana penarikan kesimpulan merupakan gambaran singkat dari hasil penelitian secara keseluruhan. Kemudian peneliti juga memberikan saran - saran yang dapat digunakan oleh perusahaan untuk mengadakan perbaikan metodologi atau langkah - langkah dalam menyelesaikan masalah perusahaan. Kemudian memberikan saran kepada penelitian berikutnya yang akan mengangkat masalah atau isu yang sama.

Secara garis besar langkah - langkah penelitian terdapat rumusan masalah yang memuat permasalahan apa saja yang akan dibahas ataupun diselesaikan, tujuan penelitian yaitu tujuan mengadakan penelitian tersebut. Kemudian pengumpulan data, pengumpulan data yang dimaksut berisi data - data apa saja yang digunakan dalam melakukan analisa, setelah data dikumpulkan kemudian data diolah menggunakan metode yang telah dipilih. Data yang telah diolah dan mendapatkan hasil dilakukan analisa serta pembahasannya secara terperinci, dan yang terakhir adalah memberikan kesimpulan serta saran atas penelitian yang telah dilakukan.

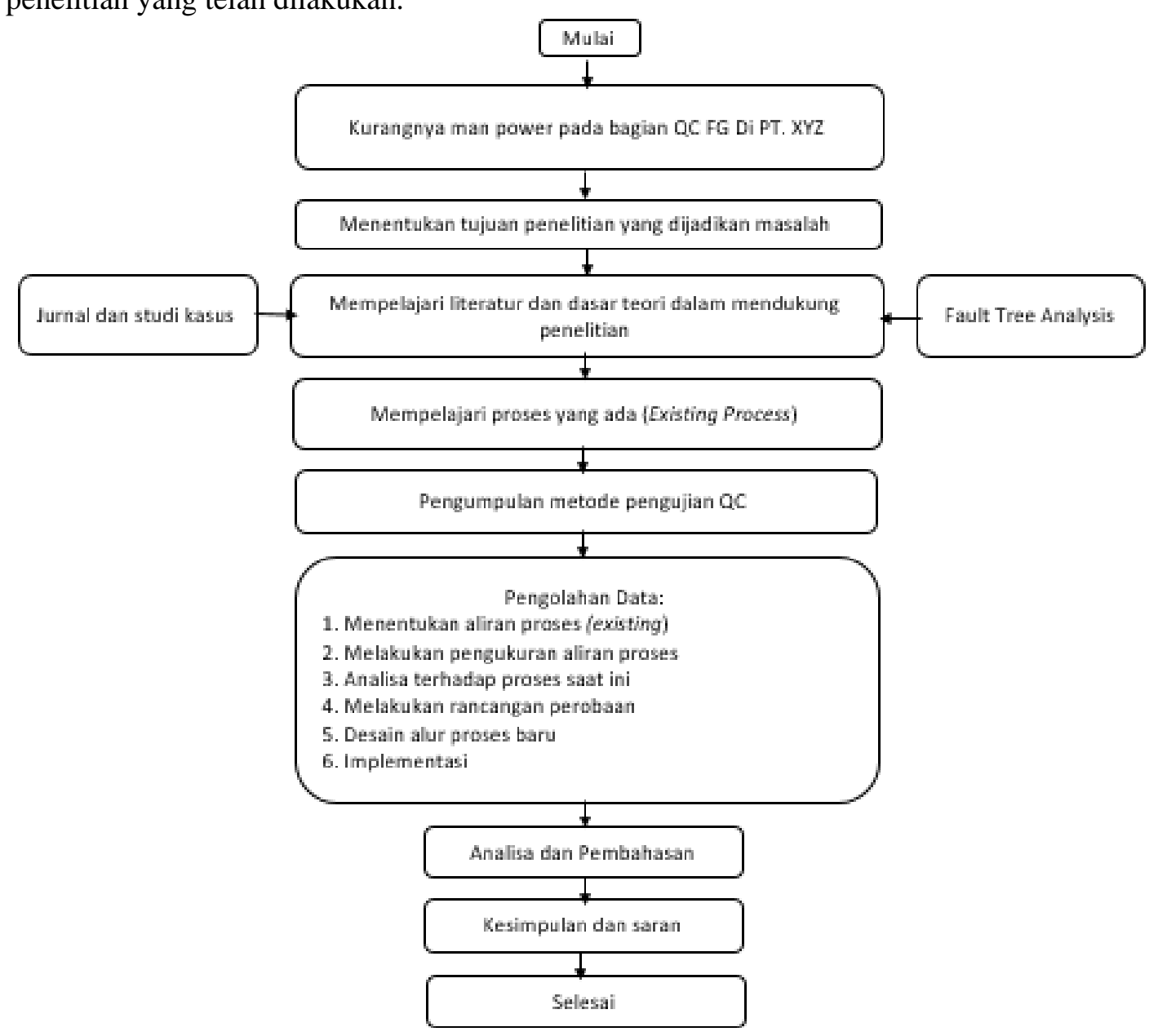

Gambar 1 Flow Chart Tahapan Penelitian 


\section{ANALISA DAN PEMBAHASAN}

3.1 Pengumpulan Data

Berikut adalah jumlah produksi ( batch) perbulannya untuk produk donut mix selama Maret - Agustus 2020:

Tabel 1 Data Produksi Donut Mix Periode Maret - Agustus 2020

\begin{tabular}{|c|c|}
\hline Bulan & $\begin{array}{c}\text { Jumlah } \\
\text { (Batch) }\end{array}$ \\
\hline Maret & 21 \\
\hline April & 23 \\
\hline May & 53 \\
\hline Juni & 25 \\
\hline Juli & 23 \\
\hline Agustus & 46 \\
\hline
\end{tabular}

Selain pengambilan data dilakukan juga obeservasi ke area Quality untuk mengamati secara langsung apa saja yang terjadi di tempat penelitian, dalam hal ini, obyek observasi adalah lab QC. Berdasarkan observasi yang telah dilakukan penyusun, hasilnya adalah sebagai berikut:

Tabel 2 Tabel Observasi

\begin{tabular}{|c|l|l|}
\hline No & \multicolumn{1}{|c|}{ Kendala } & \multicolumn{1}{c|}{ Pengaruh } \\
\hline 1. & Man power berkurang & Sampel menumpuk \\
\hline 2. & Jenis pengujian aplikasi sampel rumit & $\begin{array}{l}\text { Butuh waktu lama untuk } \\
\text { mengerjakan satu sampel }\end{array}$ \\
\hline 3. & Peralatan terbatas & $\begin{array}{l}\text { Operator mengantri peralatan yang } \\
\text { akan digunakan }\end{array}$ \\
\hline
\end{tabular}

Berdasarkan table data di atas, sementara ini dapat disimpulkan bahwa pengurangan man power sebagai dampak dari pandemi sangatlah bepengaruh terhadap efektifitas dan efisiensi pengerjaan sampel-sampel produk di departemen QC.

\subsection{Proses Pengujian Aplikasi Donut Mix (Existing)}

Tabel 3 Metode Pengujian Donut Mix (Existing)

\begin{tabular}{|c|c|}
\hline NO & Aktivitas \\
\hline 1 & $\begin{array}{l}\text { Masukkan semua bahan kedalam mixer berkapasitas } 3 \mathrm{~kg} \text {, aduk bahan menggunakan } \\
\text { baling spiral dengan speed } 1 \text { selama } 2 \text { menit. }\end{array}$ \\
\hline 2 & $\begin{array}{l}\text { Lanjutkan pengadukan dengan speed } 2 \text { selama } 10 \text { menit (suhu adonan maks. 28-33 } \\
\text { deg c). }\end{array}$ \\
\hline 3 & Diamkan adonan dalam mixer selama 2 menit. \\
\hline 4 & $\begin{array}{l}\text { Tipiskan adonan secara manual terlebih dahulu dengan roll dengan tujuan agar tidak } \\
\text { merobek adonan saat masuk ke conveyor. }\end{array}$ \\
\hline 5 & $\begin{array}{l}\text { Tipiskan dengan conveyor skala } 20 \mathrm{~mm} \text { (tebal adonan } 3-4 \mathrm{~cm} \text { ) dan diamkan adonan } \\
\text { diatas conveyor selama } 5 \text { menit. }\end{array}$ \\
\hline 6 & $\begin{array}{l}\text { Tipiskan kembali adonan dengan conveyor skala } 8 \mathrm{~mm} \text { (tebal adonan } 1-2 \mathrm{~cm} \text {, } \\
\text { diamkan adonan diatas conveyor selama } 2 \text { menit. }\end{array}$ \\
\hline 7 & $\begin{array}{l}\text { Tipiskan kembali adonan dengan conveyor skala } 8 \mathrm{~mm} \text { (tebal adonan } 1-2 \mathrm{~cm} \text {, } \\
\text { diamkan adonan diatas conveyor selama } 2 \text { menit. }\end{array}$ \\
\hline 8 & Cetak adonan dengan cetakan berdiameter $7,5 \mathrm{~cm}$ dan timbang \\
\hline 9 & $\begin{array}{l}\text { Masukkan ke dalam alat fermentasi selama } 40 \text { menit, dan setting RH } 0 \% \text { (hygro } 48 \\
-54 \% \text { ) dengan suhu } 400 \mathrm{C} \text { (hygro } 39-40 \text { 0C). }\end{array}$ \\
\hline 10 & $\begin{array}{l}\text { Keluarkan dari alat fermentasi dan biarkan adonan di suhu ruang } 3 \text { menit sebelum } \\
\text { digoreng. }\end{array}$ \\
\hline 11 & $\begin{array}{l}\text { Goreng dalam alat penggorengan, suhu } 160-165 \text { oC (setting suhu penggorengan } \\
\text { pada suhu } 170 \text { 0C) }\end{array}$ \\
\hline
\end{tabular}


Langkah pertama yang harus dilakukan adalah dengan menganalisa atau mendapatkan data proses pada produk existing. Hal ini dilakukan untuk dijadikan sebagai bahan acuan atau untuk standarisasi, Sehingga akan ada bahan pembanding dengan hasil perbaikan pada penelitian ini. Berikut ini adalah beberapa data proses pada produk existing yang sudah berhasil penyusun rangkum dan akan dijadikan sebagai acuan dalam penelitian ini:

Tabel 4 Data Waktu Proses Pengujian Donut Mix (Existing)

\begin{tabular}{|c|c|c|c|c|c|}
\hline No & Proses & Aktivitas & $\begin{array}{l}\text { Waktu } \\
\text { (Menit) }\end{array}$ & VA & NVA \\
\hline 1 & Prepare & Menyiapkan bahan dan alat yang akan digunakan & 5 & $\sqrt{ }$ & \\
\hline 2 & Mixing & $\begin{array}{l}\text { Masukkan semua bahan kedalam mixer, aduk } \\
\text { bahan menggunakan baling spiral dengan speed } 1 \\
\text { selama } 2 \text { menit. }\end{array}$ & 2 & & $\sqrt{ }$ \\
\hline 3 & Mixing & $\begin{array}{l}\text { Lanjutkan pengadukan dengan speed } 2 \text { selama } 10 \\
\text { menit (suhu adonan } \max 28-33 \mathrm{deg} \mathrm{C} \text { ). }\end{array}$ & 10 & & $\sqrt{ }$ \\
\hline 4 & Proofing & Diamkan adonan dalam mixer selama 2 menit. & 2 & & $\sqrt{ }$ \\
\hline 5 & Moulding & $\begin{array}{l}\text { Tipiskan adonan secara manual terlebih dahulu } \\
\text { dengan roll dengan tujuan agar tidak merobek } \\
\text { adonan saat masuk ke conveyor. }\end{array}$ & 1 & $\sqrt{ }$ & \\
\hline 6 & Moulding & $\begin{array}{l}\text { Tipiskan dengan conveyor skala } 20 \mathrm{~mm} \text { (tebal } \\
\text { adonan } 3-4 \mathrm{~cm} \text { ) dan diamkan } \\
\text { adonan diatas conveyor selama } 5 \text { menit. }\end{array}$ & 5 & & $\sqrt{ }$ \\
\hline 7 & Moulding & $\begin{array}{l}\text { Tipiskan kembali adonan dengan conveyor skala } \\
9 \mathrm{~mm} \text { (tebal adonan } 1-2 \mathrm{~cm} \text {, diamkan adonan } \\
\text { diatas conveyor selama } 2 \text { menit. }\end{array}$ & 2 & & $\sqrt{ }$ \\
\hline 8 & Moulding & $\begin{array}{l}\text { Tipiskan kembali adonan dengan conveyor skala } \\
9 \mathrm{~mm} \text { (tebal adonan } 1-2 \mathrm{~cm} \text {, diamkan adonan } \\
\text { diatas conveyor selama } 2 \text { menit. }\end{array}$ & 2 & $\sqrt{ }$ & \\
\hline 9 & Moulding & $\begin{array}{l}\text { Cetak adonan dengan cetakan berdiameter 7,5 } \\
\mathrm{cm} \text { dan timbang }\end{array}$ & 8 & & $\sqrt{ }$ \\
\hline 10 & Proofing & $\begin{array}{l}\text { Masukkan ke dalam alat fermentasi selama } 40 \\
\text { menit, dan setting RH } 0 \% \text { (hygro } 48-54 \% \text { ) } \\
\text { dengan suhu 400C (hygro } 39-40 \text { degC). }\end{array}$ & 40 & & $\sqrt{ }$ \\
\hline 11 & Proofing & $\begin{array}{l}\text { Keluarkan dari alat fermentasi dan biarkan } \\
\text { adonan di suhu ruang } 3 \text { menit sebelum digoreng. }\end{array}$ & 3 & & $\sqrt{ }$ \\
\hline 12 & Frying & $\begin{array}{l}\text { Goreng dalam penggorengan, suhu } 160-165 \\
\text { deg C (setting suhu alat penggorengan pada suhu } \\
170 \mathrm{deg} \text { C) }\end{array}$ & 10 & $\sqrt{ }$ & \\
\hline \multicolumn{3}{|r|}{ Total } & 90 & & \\
\hline
\end{tabular}

Berdasarkan data waktu proses pada produk existing di atas, maka dapat disimpulkan bahwa terdapat beberapa data analisa aktifitas non value added pada produk existing tersebut seperti pada tabel di bawah ini:

Tabel 5 Analisa Aktivitas Non Value Added

\begin{tabular}{|c|c|c|c|}
\hline No & Aktivitas & $\begin{array}{l}\text { Waktu } \\
\text { (Menit) }\end{array}$ & Remark \\
\hline 1 & Prepare & 5 & Value Added \\
\hline 2 & Mixing & 12 & Non Value Added \\
\hline 3 & Moulding & 20 & Non Value Added \\
\hline 4 & Proofing & 40 & Non Value Added \\
\hline 5 & Frying & 13 & Value Added \\
\hline & Total & 90 & \\
\hline
\end{tabular}

Dari tabel di atas total waktu untuk pengujian Donut Mix adalah 90 menit atau 1.5 jam per batch, Tabel waktu aktivitas membantu untuk mengetahui kegiatan yang menguntungkan serta kegiatan yang tidak menguntungkan. 


\subsection{Analisis FTA}

Dalam membuat fault tree analysis hal pertama yang harus dilakukan adalah mengidentifikasi potensi penyebab dari kesalahan-kesalahan yang terjadi pada tiap proses yang akan dikaji sehingga diperoleh penyebab secara umum yang menyebabkan aktivitas non value added yang kemudian dijadikan acuan untuk membuat fault tree. Setelah diketahui penyebab umum yang menyebabkan aktivitas non value added.

Maka selanjutnya dilakukan break down secara terperinci dalam cabang-cabang yang membentuk fault tree, sampai ditemukan kejadian paling dasar atau disebut dengan basic event. Langkah tersebut menerangkan semua urutan sebab dan akibat yang mennyebabkan terjadinya top level event. Dalam membangun fault tree digunakan symbolsimbol tertentu yang digunakan untuk mewakili adanya sebab akibat. berikut fault tree untuk masing-masing aktivitas non value added:

\section{Mixing}

Proses mixing merupakan proses pencampuran semua bahan baku yang sudah disiapkan kedalam mesin pengaduk seperti yang sudah dijelaskan pada tabel 4.4 Berikut ini adalah analisa masalah dengan menggunakan metode FTA pada faktor Mixing:

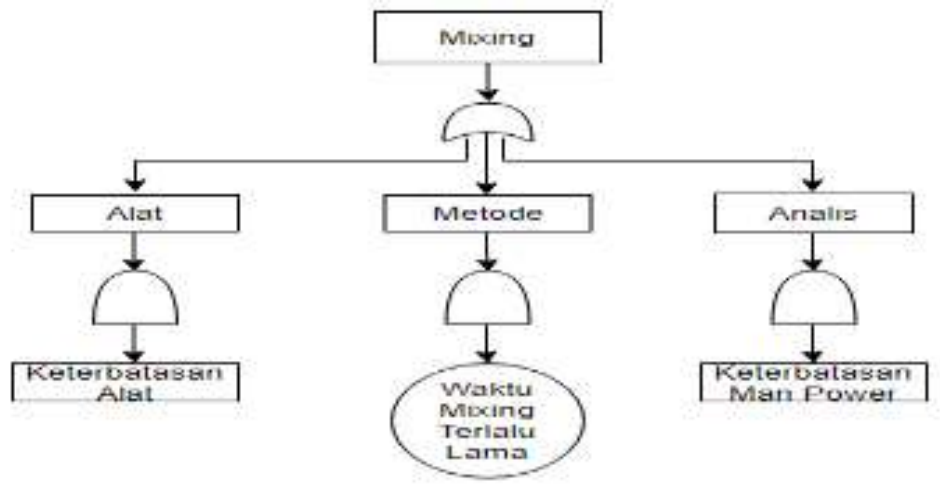

Gambar 2 Fault Tree Analysis (Mixing)

Dari Fault Tree Analysis mengenai aktivitas non value added mixing pada gambar 2 dapat disimpulkan yang menjadi penyebab non value added antara lain alat, Metode dan Analis.

\section{Moulding}

Proses moulding adalah proses pencetakan adonan yang telah di mixing sebelumnya seperti yang sudah dijelaskan pada tabel 4.4. Berikut ini adalah analisa masalah dengan menggunakan metode FTA pada faktor moulding:

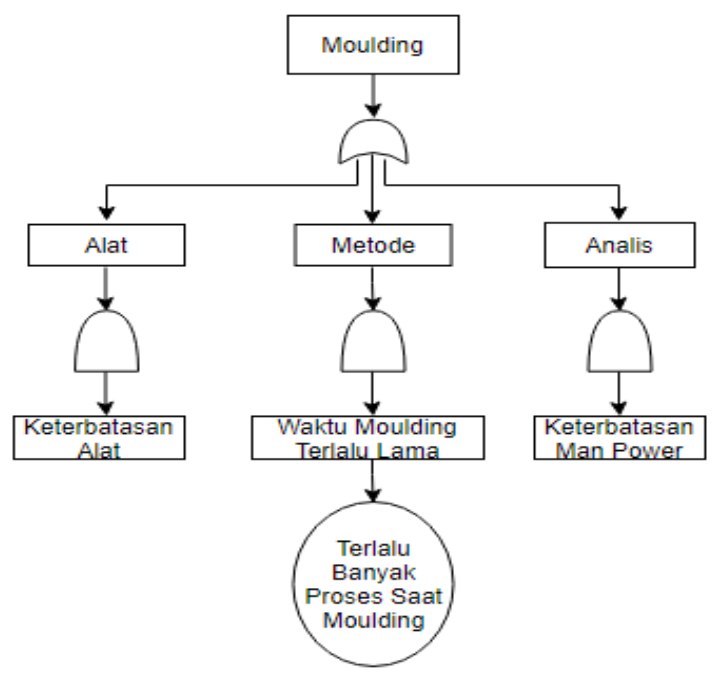

Gambar 3 Fault Tree Analysis (Moulding) 
Dari Fault Tree Analysis mengenai aktivitas non value added moulding pada gambar 3 dapat disimpulkan yang menjadi penyebab non value added antara lain alat, Metode dan Analis. Selain menggunakan metode FTA di atas, analisa masalah pada fakor ini juga dijabarkan dengan menggunakan metode $5 \mathrm{~W} 1 \mathrm{H}$.

\section{Proofing}

Merupakan proses fermentasi adonan yang sudah dilakukan pencetakan sebelumnya seperti yang terdapat pada tabel 4.4. Berikut ini adalah analisa masalah dengan menggunakan metode FTA pada faktor Proofing:

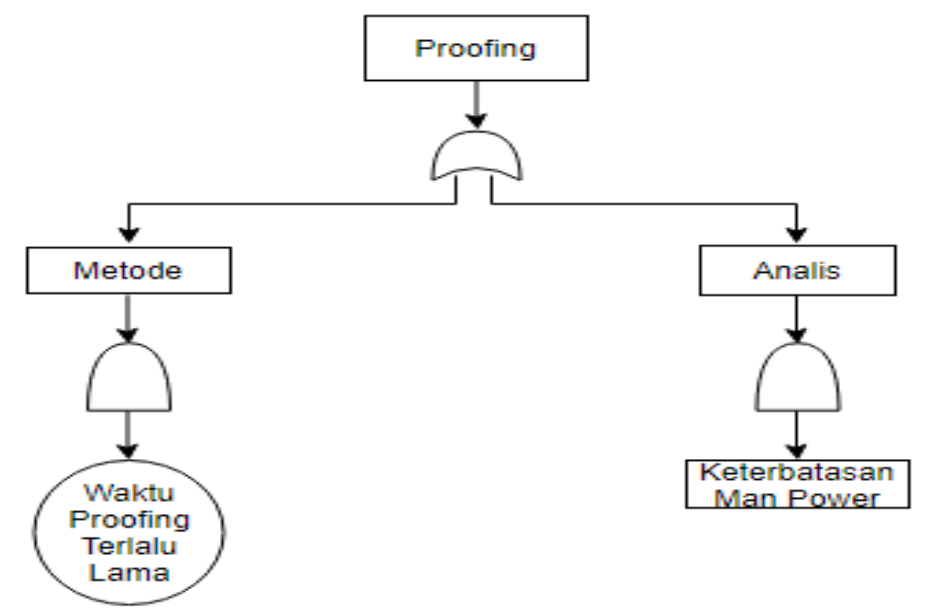

Gambar 4 Fault Tree Analysis (Proofing)

Dari Fault Tree Analysis mengenai aktivitas non value added proofing pada gambar 4 di atas, dapat disimpulkan bahwa yang menjadi penyebab non value added antara lain Metode dan Analis.

\subsection{Analisi 5W1H}

Selain menggunakan metode FTA, pada penelitian ini juga penyusun menggunakan metode $5 \mathrm{~W} 1 \mathrm{H}$ untuk mempertajam analisa masalah pada metode sebelumnya. Berikut ini adalah analisa masalah menggunakan metode $5 \mathrm{WIH}$ pada masing-masing faktor NonValue Added:

a. Mixing

Berikut ini adalah analisa masalah dengan menggunakan metode FTA pada faktor Mixing:

Tabel 6 Hasil Analisa 5W1H (Mixing)

\begin{tabular}{|l|l|l|l|l|l|l|}
\hline Faktor & \multicolumn{1}{|c|}{ What } & Who & \multicolumn{1}{|c|}{ Why } & When & Where & \multicolumn{1}{|c|}{ How } \\
\hline Alat & $\begin{array}{l}\text { Keterbatasan } \\
\text { alat }\end{array}$ & $\begin{array}{l}\text { Karena } \\
\text { keterbatasan } \\
\text { budget untuk } \\
\text { menambah } \\
\text { peralatan }\end{array}$ & $\begin{array}{l}\text { Ketika } \\
\text { masa } \\
\text { pandemi } \\
\text { covid 19 }\end{array}$ & $\begin{array}{l}\text { Lab QC } \\
\text { FG } \\
\text { (Finish } \\
\text { Good) }\end{array}$ & $\begin{array}{l}\text { Review } \\
\text { metode }\end{array}$ \\
\hline Metode & $\begin{array}{l}\text { Waktu proses } \\
\text { mixing terlalu } \\
\text { lama }\end{array}$ & QC & $\begin{array}{l}\text { Karena masih } \\
\text { belum me- } \\
\text { review metode } \\
\text { pengujian } \\
\text { aplikasi }\end{array}$ & $\begin{array}{l}\text { Ketika } \\
\text { masa } \\
\text { pandemi } \\
\text { covid 19 }\end{array}$ & $\begin{array}{l}\text { Lab QC } \\
\text { FG } \\
\text { (Finish } \\
\text { Good })\end{array}$ & $\begin{array}{l}\text { Review } \\
\text { metode }\end{array}$ \\
\hline Analis & $\begin{array}{l}\text { Keterbatasan } \\
\text { man power }\end{array}$ & QC & $\begin{array}{l}\text { Adanya } \\
\text { pengurangan } \\
\text { karyawan }\end{array}$ & $\begin{array}{l}\text { Ketika } \\
\text { masa } \\
\text { pandemi } \\
\text { covid 19 }\end{array}$ & $\begin{array}{l}\text { Lab QC } \\
\text { FG } \\
\text { (Finish } \\
\text { Good) }\end{array}$ & $\begin{array}{l}\text { Review } \\
\text { metode }\end{array}$ \\
\hline
\end{tabular}




\section{b. Moulding}

Berikut ini adalah analisa masalah dengan menggunakan metode FTA pada faktor Moulding:

Tabel 7 Hasil Analisa 5W1H (Moulding)

\begin{tabular}{|l|l|l|l|l|l|l|}
\hline Faktor & \multicolumn{1}{|c|}{ What } & Who & \multicolumn{1}{|c|}{ Why } & When & Where & \multicolumn{1}{|c|}{ How } \\
\hline Alat & $\begin{array}{l}\text { Keterbatasan } \\
\text { alat }\end{array}$ & $\begin{array}{l}\text { Karena } \\
\text { keterbatasan } \\
\text { budget untuk } \\
\text { menambah } \\
\text { peralatan }\end{array}$ & $\begin{array}{l}\text { Ketika } \\
\text { masa } \\
\text { pandemi } \\
\text { covid 19 }\end{array}$ & $\begin{array}{l}\text { Lab QC } \\
\text { FG } \\
\text { (Finish } \\
\text { Good) }\end{array}$ & $\begin{array}{l}\text { Review } \\
\text { metode }\end{array}$ \\
\hline Metode & $\begin{array}{l}\text { Terlalu } \\
\text { banyak proses }\end{array}$ & QC & $\begin{array}{l}\text { Karena masih } \\
\text { belum me- } \\
\text { review metode } \\
\text { pengujian } \\
\text { aplikasi }\end{array}$ & $\begin{array}{l}\text { Ketika } \\
\text { masa } \\
\text { pandemi } \\
\text { covid 19 }\end{array}$ & $\begin{array}{l}\text { Lab QC } \\
\text { FG } \\
\text { (Finish } \\
\text { Good) }\end{array}$ & $\begin{array}{l}\text { Review } \\
\text { metode }\end{array}$ \\
\hline Analis & $\begin{array}{l}\text { Keterbatasan } \\
\text { man power }\end{array}$ & QC & $\begin{array}{l}\text { Adanya } \\
\text { pengurangan } \\
\text { karyawan }\end{array}$ & $\begin{array}{l}\text { Ketika } \\
\text { masa } \\
\text { pandemi } \\
\text { covid 19 }\end{array}$ & $\begin{array}{l}\text { Lab QC } \\
\text { FG } \\
\text { (Finish } \\
\text { Good) }\end{array}$ & $\begin{array}{l}\text { Review } \\
\text { metode }\end{array}$ \\
\hline
\end{tabular}

\section{c. Proofing}

Berikut ini adalah analisa masalah dengan menggunakan metode FTA pada faktor Proofing:

Tabel 8 Hasil Analisa 5W1H (Proofing)

\begin{tabular}{|l|l|l|l|l|l|l|}
\hline Faktor & \multicolumn{1}{|c|}{ What } & Who & \multicolumn{1}{|c|}{ Why } & When & Where & \multicolumn{1}{|c|}{ How } \\
\hline Metode & $\begin{array}{l}\text { Waktu proses } \\
\text { terlalu lama }\end{array}$ & $\begin{array}{l}\text { Karena masih } \\
\text { belum me- } \\
\text { review metode } \\
\text { pengujian } \\
\text { aplikasi }\end{array}$ & $\begin{array}{l}\text { Ketika } \\
\text { masa } \\
\text { pandemi } \\
\text { covid 19 }\end{array}$ & $\begin{array}{l}\text { Lab QC } \\
\text { FG } \\
\text { (Finish } \\
\text { Good) }\end{array}$ & $\begin{array}{l}\text { Review } \\
\text { metode }\end{array}$ \\
\hline Analis & $\begin{array}{l}\text { Keterbatasan } \\
\text { man power }\end{array}$ & QC & $\begin{array}{l}\text { Adanya } \\
\text { pengurangan } \\
\text { karyawan }\end{array}$ & $\begin{array}{l}\text { Ketika } \\
\text { masa } \\
\text { pandemi } \\
\text { covid 19 }\end{array}$ & $\begin{array}{l}\text { Lab QC } \\
\text { FG } \\
\text { (Finish } \\
\text { Good })\end{array}$ & $\begin{array}{l}\text { Review } \\
\text { metode }\end{array}$ \\
\hline
\end{tabular}

Berdasarkan analisa masalah menggunakan metode $5 \mathrm{~W} 1 \mathrm{H}$ di atas, dapat disimpulkan bahwa akar masalah dari ketiga faktor non value added tersebut adalah harus dilakukan review terhadap metode pengujian aplikasi yang selama ini dijadikan sebagai acuan dalam mengerjakan sampel produk Donut Mix.

\subsection{Perbaikan}

Perbaikan yang dilakukan guna untuk mendapatkan hasil yang maksimal pada penelitian ini. Perbaikan tersebut, terdiri dari beberapa tahap, diantaranya:

1. Susunan Rancangan percobaan

Rancangan percobaan disusun untuk menentukan kerangka dasar kegiatan pengumpulan informasi. Dalam hal ini, rancangan percobaan dilakukan dalam rangka melakukan perbaikan pada obyek penelitian. Berikut ini adalah susunan rancangan percobaan guna memeperbaiki permasalahan yang terjadi: 
Tabel 9 Rancangan percobaan Donut mix

\begin{tabular}{|c|c|c|c|c|c|c|c|}
\hline \multirow{2}{*}{ No } & \multirow{2}{*}{$\begin{array}{c}\text { Rancangan } \\
\text { percobaan }\end{array}$} & \multirow[t]{2}{*}{ Skala } & \multicolumn{5}{|c|}{ Deskripsi } \\
\hline & & & Bahan & Mixing & Moulding & Proofing & Frying \\
\hline \multirow{4}{*}{1} & Skala kecil & \multirow{4}{*}{$\begin{array}{l}300 \\
\text { gram }\end{array}$} & $\begin{array}{l}\text { Premix } \\
300 \\
\text { gram }\end{array}$ & $\begin{array}{l}\text { Mixer } 1 \\
\mathrm{~kg}\end{array}$ & Bulatkan & \multirow{3}{*}{$\begin{array}{l}\text { Fermentasi } \\
\text { Non AC } \\
\text { Suhu 28- } \\
31^{\circ} \mathrm{C} \text {. } \\
\text { Selama } 15 \\
\text { menit } \\
\text { (tutup } \\
\text { kain) }\end{array}$} & \multirow{2}{*}{$\begin{array}{l}\text { Setting } \\
\text { suhu } \\
170^{\circ} \mathrm{C}\end{array}$} \\
\hline & $\begin{array}{l}\text { Conveyor } \\
\text { skala } 9 \mathrm{~mm}\end{array}$ & & $\begin{array}{l}\text { Ragi } 6 \\
\text { gram }\end{array}$ & $\begin{array}{l}\text { Speed } 1 \\
=1 \\
\text { menit }\end{array}$ & $\begin{array}{l}\text { Conveyor } \\
\text { skala } 9 \\
\mathrm{~mm}\end{array}$ & & \\
\hline & $\begin{array}{l}\text { Cetakan 7,5 } \\
\mathrm{cm}\end{array}$ & & $\begin{array}{l}\text { Air } 130 \\
\mathrm{ml}\end{array}$ & $\begin{array}{l}\text { Speed } 2 \\
=3 \\
\text { menit }\end{array}$ & $\begin{array}{l}\text { Cetakan } \\
7,5 \mathrm{~cm}\end{array}$ & & $\begin{array}{l}5 \\
\text { menit }\end{array}$ \\
\hline & $\begin{array}{l}\text { Fermentasi } \\
\text { Non AC } 15 \\
\text { menit }\end{array}$ & & & & & & \\
\hline \multirow{4}{*}{2} & Skala kecil & \multirow{4}{*}{$\begin{array}{c}300 \\
\text { gram }\end{array}$} & $\begin{array}{l}\text { Premix } \\
300 \\
\text { gram }\end{array}$ & $\begin{array}{l}\text { Mixer } 1 \\
\mathrm{~kg}\end{array}$ & Bulatkan & \multirow{4}{*}{$\begin{array}{c}\text { Setting } \\
\text { RH } 0 \% \\
\text { (hygro } 48 \\
-54 \% \text { ) } \\
\text { dengan } \\
\text { suhu } 40^{\circ} \mathrm{C} \\
\text { (hygro } 39 \\
-40^{\circ} \mathrm{C} \text { ). } \\
\text { Waktu } 15 \\
\text { menit }\end{array}$} & \multirow{2}{*}{$\begin{array}{l}\text { Setting } \\
\text { suhu } \\
170^{\circ} \mathrm{C}\end{array}$} \\
\hline & $\begin{array}{l}\text { Conveyor } \\
\text { skala } 9 \mathrm{~mm}\end{array}$ & & $\begin{array}{l}\text { Ragi } 6 \\
\text { gram }\end{array}$ & $\begin{array}{l}\text { Speed } 1 \\
=1 \\
\text { menit }\end{array}$ & $\begin{array}{l}\text { Conveyor } \\
\text { skala } 9 \\
\mathrm{~mm}\end{array}$ & & \\
\hline & $\begin{array}{l}\text { Cetakan 7,5 } \\
\mathrm{cm}\end{array}$ & & $\begin{array}{l}\text { Air } 130 \\
\mathrm{ml}\end{array}$ & $\begin{array}{l}\text { Speed } 2 \\
=3 \\
\text { menit }\end{array}$ & $\begin{array}{l}\text { Cetakan } \\
7,5 \mathrm{~cm}\end{array}$ & & $\begin{array}{l}5 \\
\text { menit }\end{array}$ \\
\hline & $\begin{array}{l}\text { Proofing } 15 \\
\text { menit }\end{array}$ & & & & & & \\
\hline
\end{tabular}

\section{Hasil Percobaan}

Setelah langkah perbaikan dilakukan berdasarkan rancangan percobaan yang telah disusun, maka berikut ini adalah hasil dari rancangan percobaan tersebut:

Tabel 10 Hasil Percobaan

\begin{tabular}{|c|c|c|}
\hline Rancangan percobaan & $\begin{array}{c}\text { Fermentasi Non AC } \\
\left(28-31^{\circ} \mathrm{C}\right)\end{array}$ & $\begin{array}{c}\text { Alat fermentasi } \\
(\mathrm{RH} 48-54 \%), 40^{\circ} \mathrm{C}\end{array}$ \\
\hline & 15 menit & 15 menit \\
\hline Color Aplication & OK & $\mathrm{OK}$ \\
\hline Taste Aplication & OK & OK \\
\hline Structure Aplication & Not OK & OK \\
\hline Texture Aplication & Not OK & OK \\
\hline Diametre & Not OK & OK \\
\hline Dimention & Not OK & $\mathrm{OK}$ \\
\hline \multirow[b]{2}{*}{ Apperance } & skam $9 \mathrm{~mm}$ & $\sin \sin x$ \\
\hline & & \\
\hline
\end{tabular}

Berdasarkan data dari hasil percobaan tersebut, dapat disimpulkan sebagai berikut:

- Untuk Mini Aplikasi yang bisa dilakukan pengecekan Dimensi, perlu dicetak menggunakan cetakan.

- Hasil Fermentasi menggunakan proof box dinilai mirip dengan existing, dinilai dari parameter warna, rasa, struktur, texture dan dimensi produk. 
Setelah rancangan percobaan dilakukan, maka selanjutnya dilakukan tahap finalisasi. Berikut ini langkah-langkahnya:

a. Metode pengujian aplikasi

Untuk mendapatkan data dan hasil yang akurat dari rangcangan percobaan perbaikan yang sudah dilakukan, maka dilakukanlah metode pengajuan aplikasi. Berikut ini adalah metode pengujian aplikasi (After) pada rancangan percobaan perbaikan dalam penelitian ini:

Tabel 11 Metode Pengujian Aplikasi (After)

\begin{tabular}{|c|l|}
\hline No & \multicolumn{1}{|c|}{ Uji Aplikasi } \\
\hline 1 & Masukan semua bahan kedalam mixer berkapasitas $1 \mathrm{~kg}$ \\
\hline 2 & Aduk dengan kecepatan rendah (speed 1 ) selama 1 menit \\
\hline 3 & Aduk dengan kecepatan sedang (speed 2 ) selama 3 menit hingga merata \\
\hline 4 & Bulatkan adonan kemudian tipiskan menggunakan rolling pin \\
\hline 5 & cetak menggunakan dough sheeter skala 9 mm dan cetakan donut $7,5 \mathrm{~cm}$ \\
\hline 6 & Timbang adonan sebelum masuk alat fermentasi \\
\hline \multirow{3}{*}{7} & Lakukan fermentasi menggunakan alat fermentasi dengan Setting : \\
\cline { 2 - 2 } & - RH $0 \%$ (hygro $48-54 \%$ ) \\
\cline { 2 - 2 } & - suhu $40^{\circ} \mathrm{C}$ (hygro $39-40^{\circ} \mathrm{C}$ ) \\
\cline { 2 - 2 } & - waktu 15 menit \\
\hline \multirow{2}{*}{8} & $\begin{array}{l}\text { Goreng } \text { donut } \text { menggunakan penggorengan dengan suhu } 170^{\circ} \mathrm{C} \text { selama } 5 \text { menit, } \\
\text { hingga matang merata }\end{array}$ \\
\hline 9 & Tiriskan donut dan diamkan hingga suhu $<30^{\circ} \mathrm{C}$ \\
\hline 10 & Lakukan pengamatan semua parameter QO \\
\hline
\end{tabular}

b. Evaluasi hasil perbaikan

Berikut ini adalah rangkuman dari evaluasi hasil perbaikan yang telah dilakukan melalui rancangan percobaan yang sudah dijalankan selama penelitian berlangsung:

Tabel 12 Hasil Evaluasi Perbaikan

\begin{tabular}{|c|c|c|c|}
\hline No & Aktivitas & $\begin{array}{c}\text { Waktu } \\
\text { (Menit) }\end{array}$ & Remark \\
\hline 1 & Prepare & 5 & Value Added \\
\hline 2 & Mixing & 3 & Value Added \\
\hline 3 & Moulding & 3 & Value Added \\
\hline 4 & Proofing & 15 & Value Added \\
\hline 5 & Frying & 5 & Value Added \\
\hline & Total & 31 & \\
\hline
\end{tabular}


c. Implementasi

Tahap akhir dalam percobaan perbaikan ini yaitu tahap implementasi. Berikut ini adalah tabel data implementasi pada penelitian ini:

Tabel 13 Data sebelum dan sesudah proses pebaikan

\begin{tabular}{|c|c|c|c|c|}
\hline \multirow{2}{*}{ No } & \multirow{2}{*}{ Proses } & \multicolumn{2}{|c|}{ Waktu Proses (Menit) } & \multirow{2}{*}{$\begin{array}{c}\text { Time Reduction } \\
\text { (Menit) }\end{array}$} \\
\cline { 3 - 4 } & & Sebelum & Sesudah & 0 \\
\hline 1 & Prepare & 5 & 5 & 9 \\
\hline 2 & Mixing & 12 & 3 & 17 \\
\hline 3 & Moulding & 20 & 3 & 25 \\
\hline 4 & Proofing & 40 & 15 & 8 \\
\hline 5 & Frying & 13 & 5 & 59 \\
\hline & Total & 90 & 31 & \\
\hline
\end{tabular}

Berdasarkan data pada tabel di atas, dapat disimpulkan bahwa waktu pengerjaan pada beberapa proses, telah terjadi pengurangan waktu yang sangat signifikan. Hal ini berbanding terbalik dengan sebelum dilakukan perbaikan. Dengan demikian, penerapan metode Fault Tree Analysis (FTA), Value added non value added dan 5W1H pada penelitian ini terbukti dapat mengurangi waktu proses sehingga dapat meningkatkan efektifitas dalam bekerja.

\section{KESIMPULAN}

Berdasarkan evaluasi, pengukuran dan analisis yang telah dilakukan dalam penelitian ini yaitu menggunakan metode FTA, didapatkan proses yang merupakan non value added yaitu proses mixing yang terlalu lama, terlalu banyak proses saat moulding dan waktu proofing yang terlalu lama sehingga kurang efektif. Dilihat dari analisa existing pada metode pengujian aplikasi sampel Donut Mix, waktu yang dibutuhkan untuk mengerjakan satu sampel tersebut adalah 90 menit. Setelah dilakukan analisa perbaikan menggunakan metode $5 \mathrm{~W} 1 \mathrm{H}$, didapatkan bahwa perlu meriview metode pengujian yang lebih efektif. Dapat ditarik kesimpulan dari hasil rancangan percobaan tersebut bahwa perlu adanya pengurangan - pengurangan aktivitas yang membutuhkan waktu lama. Berdasarkan perhitungan efektivitas metode pengujian satu sampel Donut Mix sebelum perbaikan membutuhkan waktu 90 menit, setelah dilakukan perbaikan waktu yang dibutuhkan hanya 31 menit, jadi penurunan waktu sebanyak 59 menit. Sehingga dengan metode pengujian aplikasi yang baru lebih efektif.

\section{DAFTAR PUSTAKA}

Bakhtiar, S, Tahir, S dan Hasni A.R, 2013, Analisa Pengendalian Kualitas Dengan Menggunakan Metode SQC, Jurnal Malikussaleh Industrial Engineering, Vol. 2, No.1, Maret 2013, 29-36 ISSN: 2302 934X

Choirul Bashori. 2017. Analisis Penyebab Kecacatan Kain Menggunakan Metode Fault Tree Analysis (FTA) dan Fuzzy Failure Mode and Effect Analysis (Fuzzy FMEA) Di Unit Weaving I. Skripsi. Fakultas Sains dan Teknologi. Universitas Islam Negeri Sunan Kalijaga Yogyakarta

Dewi, L.T., dan Dewa , P.K., (2005), Implementasi Fault Tree Analysis Pada Sistem Pengendalian Kualitas Prosiding Seminar Nasional II , Forum Komunikasi Teknik Industri, Yogyakarta

Dianatussoliha, 2019, Analisa Pengendalian Kualitas Komponen Swiftrun Divisi (CT) Componen Treatment Di PT. Panarub Industry, Laporan Kerja Praktek, Jurusan Teknik Industri FT UMT, Tangerang.

Djamal, N dan Hazizi, R, 2014, Identifikasi dan Rencana Perbaikan Penyebab Delay Produksi Melting Proses Dengan Konsep Fault Tree Analysis (FTA) di PT. XYZ, Jurnal Intech Teknik Industri ISSN: 2407-781x.

Evans, James R. (1994). Berpikir Kreatif, dalam Pengambilan Keputusan dan Manajemen. Jakarta: Bumi Aksara 
Fauzi Y,A dan Aulawi, H, 2016, Analisis Pengendalian Kualitas Produk Peci Jenis Overset Yang Cacat Di PD. Panduan Illahi Dengan Menggunakan Metode Fault Tree Analysis (FTA) Dan Metde Failure Mode And Effect Analysis (FMEA), Jurnal Kalibrasi, Vol.14, No.1, 2016, 2302-7320.

Gaspersz, Vincent, (2002) Total Quality Manajemen, Improve. Jakarta: Gramedia Pustaka Utama

Pakpahan, A.K, Suhardini, D dan Ehys,P, 2017, Peningkatan Produktivitas Pada PT. Hamson Indonesia, Jurnal Teknik dan Ilmu Komputer, Vol. 06, No. 24, Oktober 2017.

Papadopoulos, 2004, faut and event tree analysis "Uncertanty handling formulation analysis". Vol. 31, No. (1), 86 -107.

Permatasari, I., 2019, Penerapan Metode Fault Tree Analysis Dan Failure Mode And Effect Anlysis Untuk Meningkatkan Kualitas Produk Busana Muslim (Studi Kasus Di Brand X), Skripsi, Jurusan Manajemen, FE UPI, Bandung.

Sadiman, J.. (1983). Resesi Ekonomi Dunia Dan Kaitannya Dengan Opec 19731982 Dan Proyek Energi Dunia . Jakarta: Ppm

Wijaya kususma, (2008) Design of experiment improve "Pengaruh penyebab dominan terhadap penyebab masalah" Jakarta: Gramedia Pustaka Utama 